Ecological Economics

February 2015, Volume 110 Pages 81-88

http://dx.doi.org/10.1016/j.ecolecon.2015.01.002

http://archimer.ifremer.fr/doc/00248/35884/

(c) 2015 Elsevier B.V. All rights reserved.

\title{
Biodiversity offset markets: What are they really? An empirical approach to wetland mitigation banking
}

\author{
Vaissière Anne-Charlotte $^{1, *}$, Levrel Harold ${ }^{2}$ \\ ${ }^{1}$ IFREMER, UMR AMURE, Marine Economics Unit, ZI Pointe du Diable, CS 10070, F-29280 Plouzané, \\ France \\ 2 IFREMER, UMR AMURE, Marine Economics Unit, CIRED, UMR 8568 CNRS ENPC CIRAD EHESS \\ AgroParisTech, 45 bis avenue de la Belle Gabrielle, F-94736 Nogent-sur-Marne, France \\ * Corresponding author : Anne-Charlotte Vaissière, email adress : anne.charlotte.vaissiere@gmail.com \\ harold.levrel@agroparistech.fr
}

\section{Highlights}

Mitigation banking is a hybrid form halfway between a market and a hierarchy. Its features are well-adapted to implement public policy dealing with biodiversity. It is a useful decentralized regulation tool for biodiversity conservation.

Keywords : Biodiversity offset, Market, Hybrid form, Mitigation banking, Wetlands 
Introduction

Market-based instruments, among them tradable permits, are increasingly being used to manage environment and natural resources such as transferable fishing quotas and the carbon market (Pirard 2012). For a long time, the only existing environmental offset market was the carbon market (Pirard 2012). Other biodiversity offset markets are currently emerging, such as species and streams banking, but neither is as mature as wetland banking in the United States (Madsen et al. 2011). Most lessons for environmental markets are drawn from the latter (NRC 2001; Bendor et al. 2011). The aim of wetland mitigation banking is to restore large scale wetland areas in order to compensate for impacts on nearby, similar wetlands (Hough and Robertson 2009). Exchanges between the gains from the restoration and the losses from the impacts are carried out through a market of “mitigation credits” under the control of regulators. The ultimate goal is to achieve no net loss of wetland in the service area (USACE and USEPA 2008).

Grey and scientific literature use the word "market," or combined words using this term such as “market-based instrument” (Eftec et al. 2010), "biodiversity market” (Madsen et al. 2010, 2011), “credit market” (Van Teeffelen et al. 2014), or “permit market” (Wissel and Wätzold 2010), when they refer to the mitigation banking system; however, some authors question the real nature of this so-called "market”. For instance, Boisvert et al. (2013) question the limits of classifying biodiversity offsets as market based instruments, but they do not give criteria to define them, and Vatn (2014) gives a standardized description of trade based biodiversity offsets which are "complete markets with intermediaries”. However, the latter two articles are based on descriptive theoretical approaches and do not provide empirical evidence to support their assumptions.

To address this lack of empirical analysis of the "market nature" of wetland mitigation banking system, we carried out a field research study with actors in the wetland mitigation banking system in Florida, the region with the largest area covered by mitigation banks (Regulatory In lieu fee and Bank Information Tracking System (RIBITS)). Using this empirical evidence, the present paper describes the functioning of the mitigation banking system (section 2.1) and shows that wetland mitigation banking is a hybrid form rather than a pure "market". To do this, it uses three complementary approaches: a conventional economic approach (section 2.2), an empirical sociological approach (section 2.3) and a new institutional economics theory approach (section 2.4). 
1 Materials and methods

\subsection{Field research on the "state of wetlands": Florida}

Field research was carried out in Florida in 2013. Around 20 mitigation bank locations were toured and 54 face-to-face semi-structured interviews were carried out with various actors of the mitigation banking system. All categories of persons involved in the mitigation banking system, except developers, were interviewed. Among the 54 interviewees, 20 are environmental consultants, 28 have a role in the mitigation bank project (as a landowner, a manager or a mixed status, including other tasks such as operating the bank or selling the credits), 4 are brokers, 7 are regulators, and 6 belong to other professions (e.g. lawyer, academic) (Table 1). As shown in Table 1, among these 54 persons, 36 have only one role, 12 combine 2 roles, 5 combine 3 roles, and one combines 4 roles. Most of them are environmental consultants and mitigation bankers. In order to keep the interviewees anonymous, no names of banks or respondents are given.

These interviews provided information on 71 of the 91 approved or pending banks at the time of the field work. The qualitative and quantitative information from the interviews and from some shared documents have been gathered in a database. Some qualitative information has been transformed to quantitative data when it was possible and relevant. Qualitative data were necessary to describe the mitigation banking system. These data enabled us to describe step by step the mitigation banking system and then to define its organizational nature using the three complementary frameworks we present in the following section (1.2).

\subsection{Three complementary frameworks to analyze what counts as a market}

\subsubsection{A conventional economic approach}

From a conventional economic point of view, a market is characterized by a demand, a supply, a transaction of goods or services and a price (Samuelson and Nordhaus 1948). There are also criteria of property rights, information on goods and services, real location (e.g. a territory) or virtual location (e.g. stock market), level of competition, and rules organizing transactions. These nine criteria are used to define a market with a conventional economic approach. 


\subsubsection{An empirical sociological approach}

Rosenbaum (2000) proposes a critical synthetic approach to the market definition with a view to operationalize the notion and to locate it among all existing organizational forms. This approach takes into account the sociological aspects of the way markets function, in addition to the "technical characteristics" of the economic definition of markets (section 1.1.1). There is a gradient between a pure market and a hierarchy. Rosenbaum's approach suggests criteria to distinguish markets from other organizational forms, based on the observation that "many economists find markets almost everywhere on Earth and in history” (Rosenbaum 2000, p. 1). If the following criteria are met, then the observed trade can be described as market trade.

- "Voluntarity" : the freedom to choose an alternative to the transaction or to withdraw from the transaction if no alternative exists;

- Specificity: there is mutual agreement of both parties on the exact conditions of the terms of the transaction;

- Regularity and typification: traded goods, their prices, and in some cases the two parties should be similar for a number of significant transactions on a significant period of time. It is not an isolated trade and traded goods are a priori known;

- Competition (in the Simmelian sense): indirect conflict conducted in parallel by sellers and buyers, with the temporary possibility of maintaining an information asymmetry on transactions in order to provide opportunities for trade preferred by buyers or sellers. It approaches the neoclassical sense of competition on one point: monopsony and monopoly without the possibility of withdrawal from the transaction are not considered as competitive situations.

Thus, we have four criteria for defining a market from an empirical sociological approach.

\subsubsection{A new institutional economics theory approach}

Another way to provide a detailed definition of different organizational forms from an economic point of view is to use the new institutional economics theory (Williamson 1985, 1991, 1996). The new institutional economics perspective focuses on institutional or organizational innovations as a way to organize certain transactions more efficiently: here, to carry out ecological compensation. Three main organizational forms coordinate transactions: markets (as defined above), hierarchies (command and control), or hybrid forms (combining features of markets and hierarchies). This paper focuses on hybrid forms since they seem to be the most appropriate way to describe the mitigation banking system. 
According to Ménard (2004, p. 351), hybrid forms "rely on partners who maintain distinct property rights and remain independent residual claimants”. Even if they are diverse, they show recurrent empirical regularities: pooling resources, contracting and competing (Table 2). Hybrid forms have a particular combination of market and hierarchy characteristics that makes them better adapted to the characteristics of the transactions they are aimed at organizing.

Thus, we have three criteria to define a market from the new institutional economics theory approach.

\section{Results and discussion}

\subsection{Functioning of the wetland mitigation banking system in Florida}

The mitigation banking system is based on the Clean Water Act (CWA), which requires compensation for impacts on wetlands in order to reach a goal of no net loss of this type of ecosystem in the United States (Hough and Robertson 2009). The normative aim of no net loss is to reach equivalence between ecological function losses and gains. In Florida, actors are under the obligation to fulfill the requirements of ecological compensation at the federal level (United States Army Corps of Engineers (USACE)), and at the state level (Florida Department of Environmental Protection (FDEP) or Water Management Districts (WMD)). Mitigation credits are defined on a biophysical nature basis (palustrine ${ }^{1}$ emergent credits or estuarine credits for instance), and are determined by using assessment methods. Credits correspond to the extent of biodiversity loss caused by the developers and to the extent of biodiversity gain produced by a mitigation banker. The debt of the developer is expressed in mitigation credits that have to be bought from mitigation bankers who own mitigation credits approved by regulators. The geographic area within which mitigation credits can be traded is physically demarcated by a service area defined on the basis of hydrographic criteria. The three main groups of actors in this system are therefore developers, mitigation bankers and regulators (Figure 1). They interact with other actors who facilitate the transactions, such as environmental consultants, who play a key role as mediators between mitigation bankers and regulators on one hand, and between developers and regulators on the other. Environmental consultants negotiate the number of allocated or required credits, assess equivalences, decide the delineation of the service areas, and conduct the monitoring.

\footnotetext{
${ }^{1}$ Terrestrial wetlands that are not under tidal influence.
} 
2.2 Market characteristics of the mitigation banking system from a conventional economic approach

Our research in Florida suggests that the mitigation banking system is an organizational form having some of the characteristics of a market, but which is also different in several ways.

\subsubsection{Demand for mitigation credits}

Demand comes from developers of projects that have significant residual impacts ${ }^{2}$ on aquatic ecosystems, who can offset them by buying credits from mitigation bankers in order to fulfill the regulatory requirement of no net loss. Credits correspond to the type of ecosystems specifically impacted. This demand is based on the level of application and of the requirements of the regulations for compensation: i.e. the regulators determine the quantity and quality of credits the developer must buy. This demand is negotiated between the regulators and the developer, usually via an environmental consultant.

The 2008 Final Rule (USACE and USEPA 2008) sets a preference for mitigation banking ${ }^{3}$. During the permitting process, the regulator in charge of the permit application of a developer may ask for additional information regarding ecological compensation to prepare the final application document for the permit. This is an expensive and time consuming requirement for developers to justify the fact that they cannot use a mitigation bank.

\subsubsection{Supply for mitigation credits}

Supply is linked to the implementation of an ecological restoration project by mitigation bankers, for which the regulator in charge of compensatory mitigation (federal and Floridian regulators) releases a certain number of mitigation credits. Credits are released to mitigation bankers following a schedule based on the achievement of ecological performance criteria ${ }^{4}$ defined in the Mitigation Banking Instrument of the bank. This supply is negotiated between the regulators and the mitigation bankers, usually via an environmental consultant. There are two main types of mitigation banks, depending on whether actors are public or private entities. Private banks gather private actors that own and manage the bank.

\footnotetext{
${ }^{2}$ In the mitigation hierarchy, developers must prefer avoidance and minimization before going to compensation. In this last step of the hierarchy, residual impacts may be compensated.

${ }^{3}$ This is a preference hierarchy with first mitigation banking, then in lieu fee (ILF) and finally permittee responsible mitigation (PRM) (33 Code of Federal Rules 332.3 (b)).

${ }^{4}$ Some credits are released at the beginning of the project: for instance, for the setting of the conservation easement or of the financial assurances, and for the effective realization of ecological engineering actions.
} 
Public/private banks consist of a partnership between a public entity (a state, a county or a WMD) and a private entity. One entity owns the land and one entity implements and manages the bank. Financial arrangements are varied (Box 1). Private banks usually do not like this second type of bank. It strikes them as a form of unfair practice for two reasons: (1) the land, which is often the largest investment, is provided by the public entity, and (2) there is a potential for conflict of interest if the regulator involved in that mitigation bank project is also involved in the permit approval for another bank in the same service area. Moreover, the fact that taxpayers must pay for the investment in these public/private banks is poorly perceived, even if the funds collected by selling the credits are then spent on other environmental actions.

Mitigation bankers invest in zones where development projects are expected and in restoration projects that would provide demanded types of credits. Hence, most of the time, mitigation banks are located in rural zones close to expanding urban zones (Ruhl and Salzman 2006). Planned public projects, such as road projects of the Florida Department of Transportation (FDOT), are usually announced well in advance and attract mitigation banks in their vicinity. Local developers may invest in a mitigation bank in order to be sure there will be available credits in the area in which they will have to compensate for impacts. There is currently a complementary and opposite relationship between mitigation banks supply and housing supply. With the global financial crisis, the demand for housing is decreasing, which logically leads to a decrease of the demand for mitigation credits. However, mitigation bankers feel this is a temporary effect: land is affordable because it is less in demand for other uses. Mitigation banking actors are confident that the economy will recover soon so they are stocking up on compensatory solutions for a lower cost. Another interesting phenomenon is that some lands which were purchased for urbanization are now being turned into mitigation banks, because this sector is more profitable in certain areas. However, the public demand is still strong and public entities such as the $\mathrm{FDOT}^{5}$ are currently the major clients of some banks (41 of 70 approved banks have sold credits to the FDOT).

The emergence of the mitigation banking system has led to the creation of a sector with new professions, such as brokers of mitigation credits, or environmental consultants specialized in turnkey mitigation banking solutions (they create, manage and operate the bank). The private lobby of this new sector is quite powerful with the National Mitigation Banking Association

\footnotetext{
${ }^{5}$ Jacksonville District has the higher number of total lane construction km between 2000 and 2007 with 96,000 km (BenDor et al. 2011).
} 
(NMBA) and its local branches such as the Florida Mitigation Banking Association (FMBA). In 2011, 40 of the 64 approved banks with a federal permit in Florida, that is 60\%, were members of the FMBA. At present, this association is focused on negotiating the definition of wetlands and the types of financial instrument that mitigation bankers may use to provide financial assurances.

\subsubsection{The traded environmental commodity}

Mitigation credit does not correspond to a commodity under the economic theory; it is more a negotiation process than a market for goods.

First, the credit is subject to a double negotiation, on both the quantity and the price. Each state decides whether they wish to carry out a regulation at two scales. In Florida, even if most of the time the number of credits required by both regulators are similar, the USACE and the FDEP or the WMD do not have the same definition of wetlands especially for uplands surrounding them. The USACE only approves palustrine forested credits for a strict 100 meters buffer surrounding the wetlands. The FDEP investigates in greater detail the role of the forest as a water catchment area for the wetland that is targeted for restoration. Federal and state regulators may thus have a different assessment of the number of credits needed to compensate for an impact and the number of credits approved for the implementation of a bank. Mitigation bankers have two columns in their ledgers ${ }^{6}$ : one for "federal credits" and one for "state credits". Because federal and state credits represent different appraisals of the same compensatory measure, developers do not have to buy both types of required credits; they buy “combined credits”. This means the developer pays the larger amount of required credits even if the mitigation banker withdraws the demanded federal and state credits from its ledger. This mechanism can lead to some difficulties and slowness, but the automatic double analysis of the impact and its required compensation can offer a better implementation of ecological compensation.

Second, there is no fixed currency for the credits, even within a service area. Credits are not only defined on a restored ecosystem basis but also on a used assessment method basis. For instance in Florida, the most widely used assessment method is the Uniform Mitigation Assessment Methodology (UMAM) but most of the banks established before the creation of this new method were using the ratio method, or other methods invented for a specific bank. Hence, there are both UMAM credits and ratio credits. The credits required by the developer

\footnotetext{
${ }^{6}$ Each bank has to keep an up to date ledger with debits and credits of mitigation credits.
} 
must match the type of credits that the targeted bank for the transaction is selling, so that one of them has to translate its credits to the currency of the other one.

\subsubsection{Property rights}

There is a true transfer of rights via the purchase of a credit because the landowner transfers its right of destruction at the location of the mitigation bank to the developer, in exchange for an impact on another property. However, credits do not have a physical representation within the mitigation bank. They correspond to a part of the implementation of the mitigation plan for restoration of the wetland, so that the developer is paying for a service supplied by the mitigation banker: namely, an ecological lift to the environment.

\subsubsection{Information}

The online database Regulatory In lieu fee and Bank Information Tracking System (RIBITS) managed by the USACE gathers and circulates basic information on mitigation banks and transactions undertaken. This market transparency is emphasized by regulators and mitigation bankers in order to gain the confidence of developers and the population in general (vision of a perfect competition). However, parallel knowledge networks also exist due to a history of relations between local actors. Informal relationships facilitate transactions.

\subsubsection{Size of the market}

Service areas can be defined as little markets from a spatial point of view. A service area usually corresponds to a sub-basin under the US Geological Survey classification: 1,800 km² in average (Seaber et al. 1987), which is almost the area of the Kings Canyon national park in California. In Florida, service areas range from $255 \mathrm{~km}^{2}$ (almost the area of the Dry Tortugas national park in Florida) to $3544 \mathrm{~km}^{2}$ (almost the area of the Olympic national park in Washington).

Even where there are a supply and a demand, they remain low and on a very small scale. It is possible to talk about markets on the scale of service areas but it is not possible to say that there is a mitigation credits market in the same way that there is a carbon market. Mitigation bankers may negotiate to extend the service area, usually via an environmental consultant, while regulators must ensure that the service area maintains an ecological meaning. 


\subsubsection{Level of competition}

There are some monopolistic or oligopolistic markets. In Florida, 10\% of the banks do not have any competitor. The remaining $90 \%$ of banks have overlapping service areas ${ }^{7}$, but they can continue to hold a monopoly in some parts of their service area and/or for a credit type. Mitigation banks are aware of the risk of flooding the market with credits: it would lead them to decrease the price of the credits at the risk of making the economic performance of their project decrease. In spite of this, it is now difficult, in Florida, to find potential sub-basins where development is expected which are without any mitigation bank.

An oligopolistic or monopolistic market enables mitigation banks to control, at least partially, prices that would be knocked down by free competition. In contrast to the classical analysis of the effects of oligopolies, competition remains quite high between mitigation banks at the level of a given service area. However, the result is consistent with the classical analysis: even if mitigation bankers do not agree on a price, the price remains quite high (see section 2.2.8). Hence, the whole society pays an excessive price for compensation. At first sight, this point may seem meaningless because the developers do have to pay this additional cost. But the additional cost will be transferred to the price of other goods the consumer will purchase, so it represents an additional social cost.

Established mitigation banks may lodge an appeal in order to create barriers to enter the market, or they can also use the price of the credits (Box 2). The ultimate goal of bankers is to sell their credits before there is a strong competition on their market. However, once a bank is sold out (i.e. all the credits have been released and then sold), there is an opportunity for new mitigation banks to enter the market of a service area.

\subsubsection{Price setting}

Negotiations on the credits' price, the payment plan, and the transaction take place either directly between the developer and the mitigation bankers, or via a broker. There are few brokers in Florida, they cover a large number of banks, and they have a role in balancing and stabilizing credit prices. Regulators validate upfront the number of credits allocated to the bank and the number of credits required to offset the impact, but in order to respect the principle of free competition, they are never involved in these negotiations. They validate the transaction once its terms have been defined. There is an unusual situation here: because the

\footnotetext{
${ }^{7}$ Usually 2 or 3 banks sharing at least a part of their service area with a maximum of 6 banks in Northern Florida.
} 
developer is not responsible for the success of the mitigation bank, he does not care about the quality of the credit, whereas the regulator, who is not involved in the transaction, does care about it.

In a monopoly situation, the mitigation banker sets the price of the credits a little below the cost that the developer must bear if he opts for a PRM, in order to be competitive and to encourage developers to purchase credits. However, since the 2008 Final Rule, it may be sufficient for the credits to be "affordable" to encourage their purchase, because the USACE has a soft preference for mitigation banking. In an oligopoly situation, prices adjust according to the markets on which they are traded, that is to say the service areas. If a bank is facing a tight cash flow situation, the banker can decide to reduce the price to sell more credits. Mitigation bankers can also implement marketing techniques such as advertising or a discount on the purchase of a certain quantity of credits (Table 3). The price structure in public or private/public banks has to be approved by county commissioners during a board meeting with the mayor.

The credits prices are usually high (from USD 25,000 to 200,000 per credit in Florida), so they provide a financial incentive for the emergence of banks with a fast and good return on investment ${ }^{8}$. The rarest credits, such as estuarine credits, are more expensive (at the high end of this price range). The expected income helps to counterbalance the many difficulties that arise for anyone who wants to create a mitigation bank. The upfront costs are substantial (especially the land cost) and not always feasible for mitigation banks with a low cash flow. In addition, procedures for permitting and credits approval are burdensome. Other difficulties may also arise: the non-achievement of performance criteria for the release of all the credits, the arrival of a competing bank in the service area, or the absence of the expected development, leading to a lack of demand for credits.

\subsubsection{The rules of the game of the mitigation banking system}

The mitigation banking system faced strong institutional uncertainty in the nineties. The first generation banks have sometimes created scandals (Gardner 2011, Pittman and Waite 2009), but these now appear to be increasingly rare. The rules of the game have been stabilized through an increased regulatory intervention in these market-based mechanisms. This increasing stability results in the following institutional environment.

\footnotetext{
${ }^{8}$ According to a Floridian lawyer specialized in mitigation banking we met, Floridian mitigation bankers make a $10-15 \%$ return within 5-6 years.
} 
- Since the Final Rule in 2008, the USACE has had a preference for mitigation banking compared to other existing institutional forms (permittee responsible and in-lieu fee mitigation).

- Success of the compensatory measure is the responsibility of the mitigation bank sponsor $^{9}$. Responsibility is clearer now that it is concentrated in a limited number of hands, and their actions are easier to control.

- An Inter-agency Review Team (IRT) is defined for each bank project. It gathers experts having jurisdiction or an advisory role on the proposed banking operation (e.g. on assessment methods, credit release schedule, achievement of the success criteria) during the permit application process and over the lifetime of the bank. USACE, FDEP, one of the WMD and the county are almost always involved. For specific interests, the United-States Fish and Wildlife Service (USFWS) and the Florida Fish and Wildlife Conservation Commission (FFWCC) represent fauna; and the National Marine Fisheries Service (NMFS) represents coastal and marine environments.

- A conservation easement protects the land where the restoration was carried out from all development, in perpetuity. This legal document is held by one or more third parties (usually NGOs) and is linked to the property. Non-extractive and nonimpacting uses of the property, such as access for family use or hunting, can be negotiated provided they are selective and included in the management plan of the bank.

- Financial assurances are required during the permitting process for the bank. A construction fund is established to be sure money is available to implement the management plan and the first years of monitoring. A long-term fund, based on specific financial instruments, is established to generate enough money for the maintenance of the bank in perpetuity. If a bank goes bankrupt, the money in these two funds would be transferred to a public agency or an NGO that would take over the management of the bank.

- Ecological gains and losses in the area covered by the banks or on the impacted site are increasingly valued on an ecological function basis (notes) and less on an area basis (ratios).

\footnotetext{
${ }^{9}$ The sponsor of the bank has his name on the permit. He may be the landowner but also the manager for instance.
} 
- Credits are progressively released following a schedule based on the achievement of specific, mainly ecological, performance criteria. If the criteria are not met, the credits are not released. If the situation continues, the bank may be suspended (the sale of the credits is blocked and the ledger is declared frozen).

\subsection{An organizational form with market and hierarchy characteristics from an empirical sociological approach}

Rosenbaum's criteria enable us to go deeper within the description of the mitigation banking system. Table 4 shows that even if each criterion is verified for the market, it also systematically has some features that are closer to a hierarchy.

The market characteristics of the mitigation banking system allow a certain degree of autonomy and self-adjustment between developers and mitigation banks once the number of allocated or required credits is determined by regulators.

The hierarchical dimensions of this form can be established from the important role played by regulators in this organization. Thus, the entire system is based on rules imposed by public actors: market size based on hydrologic units, the requirements of an insurance system and of a conservation easement, the environmental standards to meet, validation of the assessment methodology, setting conditions for the release of credits, and operating rules of trade.

\subsection{The mitigation banking system from a new institutional economics theory approach:} halfway between market and hierarchy

The new institutional economics approach explains how the mitigation banking system is akin to a hybrid form, halfway between market and hierarchy, with specific characteristics fitted to the organization of a particular transaction (Ménard 2003, Williamson 1991, 1996). The common characteristics of hybrid forms described by Ménard (2003) are detailed below for the mitigation banking system.

\subsubsection{Pooling resources}

There is coordination and cooperation among mitigation bankers, who choose more or fewer partners depending on how much they want to break down the tasks within the investment in a mitigation bank project. There is continuity and frequency in the relationships among the mitigation bankers of a project and between regulators and mitigation bankers. There are barriers to entering the market (e.g. the entry of a bank in a service area requires a permit) and to exiting from the market (e.g. funds for long term management have to be provided to the 
entity that recovers the banks). Mitigation credits are the common currency between the different actors of the system; their quality and quantity are negotiated and planned. Environmental consultants and regulators are trained in the implementation of assessment methods. The RIBITS database makes a great quantity of information available for all.

\subsubsection{Contracting}

The mitigation banking system can be described as a series of contracts between the groups of actors of the system in which the identity of the actors are known:

- The promise of sale and the certificate of sale for credits are the contracts between the developer and the mitigation bank;

- The permit for carrying out the mitigation bank and the Mitigation Banking Instrument are the contracts between the regulator and the mitigation bank;

- The permit obtained through the purchase of credits from mitigation bankers in order to meet the regulatory compensation requirements is the contract between the developer and the regulator.

The first type of contract is a fairly comprehensive standard complete contract, which may suggest that the mitigation banking system is a market. The two other types of contracts are closer to the types of contracts described in the case of hybrid forms. They include required items such as financial assurances, a management plan, a credit release schedule, or a preventive adaptive management plan. However, these two last types of contracts remain flexible and involve zones of uncertainty or of incompleteness in order to be interpreted and adapted to each situation. Environmental uncertainty (uncontrollable natural events for instance) gives rise to zones of uncertainty and incomplete contracts. Regulators may restrict the number of zones of uncertainty in order to be sure that they would have legal recourse in case of noncompliance (GAO 2005) or of opportunistic behaviors. The protection of the land in perpetuity satisfies the long term contract characteristic of hybrids.

The system's groups of actors are bound by a multitude of contracts:

- A private environmental consultant may be hired by mitigation banks for the duration of the permitting process and sometimes of the establishment of the bank. He is the intermediary in charge of the adaptation and of the negotiations; 
- The landowner can create a joint venture (considered as a hybrid) with the mitigation bankers so that they share the income from the sale of the credits;

- Lawyers can intervene to establish such contracts or to resolve disagreements between the parties to these contracts. It is a standard complete contract.

\subsubsection{Competing}

The internal competitive pressure is high between mitigation bankers at the level of the service areas and for certain very specific credits (which is more the case with species credits within conservation banks). However, it is not as high externally, owing to the soft preference for mitigation banking compared to other existing institutional forms (PRM and ILF). Both the risk of opportunistic behavior and the general control and stabilization of the system are globally managed by the regulators. The IRT particularly defends biodiversity interests, while from the mitigation banking industry's point of view, the lobby is in charge of the defense of mitigation bankers' interests. The preference for mitigation banking limits the risk that partners will migrate to another type of organizational form.

\section{Conclusion}

The goal of this paper was to investigate the "market” nature of wetland mitigation banking. By studying a total of 16 criteria from three complementary approaches, the paper shows that the mitigation banking system is akin in some respects to a market but that it is actually a hybrid form halfway between market and hierarchy. The market characteristics of the mitigation banking system allow a certain degree of autonomy and self-adjustment between developers and mitigation bankers, once the number of allocated or required credits has been determined by regulators. Issues of biodiversity conservation have led the regulators responsible for the implementation of the wetland mitigation banking system to take into account the complexity and geographic specificity of aquatic ecosystems. This means that there are multiple markets for wetland offsets, both geographically (service areas) and in the types of traded goods (credits). Thus, we conclude that the mitigation banking system cannot be compared with a global market such as carbon.

Oversimplifying the nature of the mitigation banking system as a "market" has led to excessive criticism of this biodiversity offset. For instance, Walker (2009) criticizes markets dedicated to nature as commodification devices, while Robertson (2004) describes mitigation banking as a risky neoliberal approach to environmental governance. However, these two 
papers do not provide empirical evidence for these claims. More recent papers have given some empirical details to clarify the risks of this system (BenDor et al. 2011, Robertson and Hayden 2008, Robertson 2009). The present paper should help to identify the opportunities and the risks of the mitigation banking system using recognized theoretical frameworks, such as the features of hybrid forms as given by the new institutional economics framework. 


\section{References}

BenDor, T.K., Riggsbee, J.A., Doyle, M. (2011). Risk and markets for ecosystem services. Environmental Science \& Technology 45(24): 10322-10330.

Boisvert, V., Méral, P., Froger, G. (2013). Market-based instruments for ecosystem services: institutional innovation or renovation? Society \& Natural Resources, 26 (10): 11221136.

Eftec, IEEP, ten Kate, K., Treweek, J., Jon Ekstrom, J. (2010). The use of market-based instruments for biodiversity protection - The case of habitat banking - Technical Report. Londres : Eftec, 264 p.

GAO [Government Accountability Office] (2005). Wetlands protection. Corps of engineers does not have an effective oversight approach to ensure that compensatory mitigation is occurring. U.S. Government Accountability Office Report GAO-05-898, Washington, D.C.

Gardner, R.C. (2011). Lawyers, swamps, and money: U.S. wetland law, policy, and politics. Washington: Island Press, 255 p.

Hough, P., Robertson, M. (2009). Mitigation under section 404 of the clean water act: where it comes from, what it means. Wetlands Ecology and Management, 17(1): 15-33.

Madsen, B., Carrol, N., Kandy, D., Bennett, G. (2011). 2011 Update. State of biodiversity markets report: offset and compensation programs worldwide. Washington: Ecosystem Marketplace, 73 p.

Madsen, B., Carrol, N., Moore Brands, K. (2010). State of biodiversity markets report: offset and compensation programs worldwide. Washington: Ecosystem Marketplace, 73 p.

Ménard, C. (2003). Économie néo-institutionnelle et politique de la concurrence les cas des formes organisationnelles hybrides. Économie Rurale, 277(1): 45-60.

Ménard, C. (2004). The economics of hybrid organizations. Journal of Institutional and Theoretical Economics, 160: 345-376.

NRC [National Research Council] (2001). Compensating for wetland losses under the Clean Water Act. Washington DC: National Academy Press.

Pirard, R. (2012). Market-based instruments for biodiversity and ecosystem services: a lexicon. Environmental Science \& Policy, 19-20: 59-68.

Pittman, C., Waite, M. (2009). Paving paradise: Florida's vanishing wetlands and the failure of no net loss. Gainesville, FL: University Press of Florida, 351 p. 
Robertson, M. (2004). The neoliberalization of ecosystem services: wetland mitigation banking and problems in environmental governance. Geoforum, 35(3): 361-373.

Robertson, M., (2009). “The Work of Wetland Credit Markets: Two Cases in Entrepreneurial Wetland Banking.” Wetlands Ecology and Management 17 (1): 35-51.

Robertson, M., Hayden, N. (2008). Evaluation of a market in wetland credits: entrepreneurial wetland banking in Chicago. Conservation Biology, 22(3): 636-646.

Rosenbaum, E.F. (2000). What is a market? On the methodology of a contested concept. Review of Social Economy, 58(4): 455-482.

Ruhl, J.B., Salzman, J. (2006). The effects of wetland mitigation banking on people. National Wetlands Newsletter, 28(2): 8-13.

Samuelson, P., Nordhaus, W. (1948). Economics. Singapore: McGraw-Hill.

Seaber, P.R., Kapinos, F.P., Knapp, G.L. (1987). Hydrologic Unit Maps: U.S. Geological Survey. Washington, DC: U.S. Geological Survey, 20 p.

USACE [United States Army Corps of Engineers], USEPA [United States Environmental Protection Agency] (2008). Compensatory mitigation for losses of aquatic resources; Final Rule. In: Federal Register, 73 Fed. Reg. 70, p. 19593-19705, 242 p.

Van Teeffelen, A.J.A., Opdam, P., Wätzold, F., Hartig, F., Johst, K., Drechsler, M., Vos, C.S., Wissel, S., Quétier, F. (2014). Ecological and economic conditions and associated institutional challenges for conservation banking in dynamic landscapes. Landscape and Urban Planning, 130: 64-72.

Vatn, A. (2014). Markets in environmental governance - From theory to practice. Ecological Economics, 105: 97-105.

Walker, S., Brower, A.L., Stephens, R.T.T., Lee, W.G. (2009). Why Bartering Biodiversity Fails. Conservation Letters, 2(4): 149-157.

Williamson, O.E. (1985). The economic institutions of capitalism: firms, markets, relational contracting. New York: The Free Press Macmillan.

Williamson, O.E. (1991). Comparative economic organization. The analysis of discrete structural alternative. Administrative Science Quarterly, 36(2): 269-296

Williamson, O.E. (1996). The Mechanisms of Governance. Oxford University Press, Oxford New York.

Wissel, S., Wätzold, F. (2010). A Conceptual Analysis of the Application of Tradable Permits to Biodiversity Conservation. Conservation Biology, 24(2): 404-411. 


\section{FIGURES CAPTIONS \& TABLES}

Figure 1: Interactions between actors of the mitigation banking system

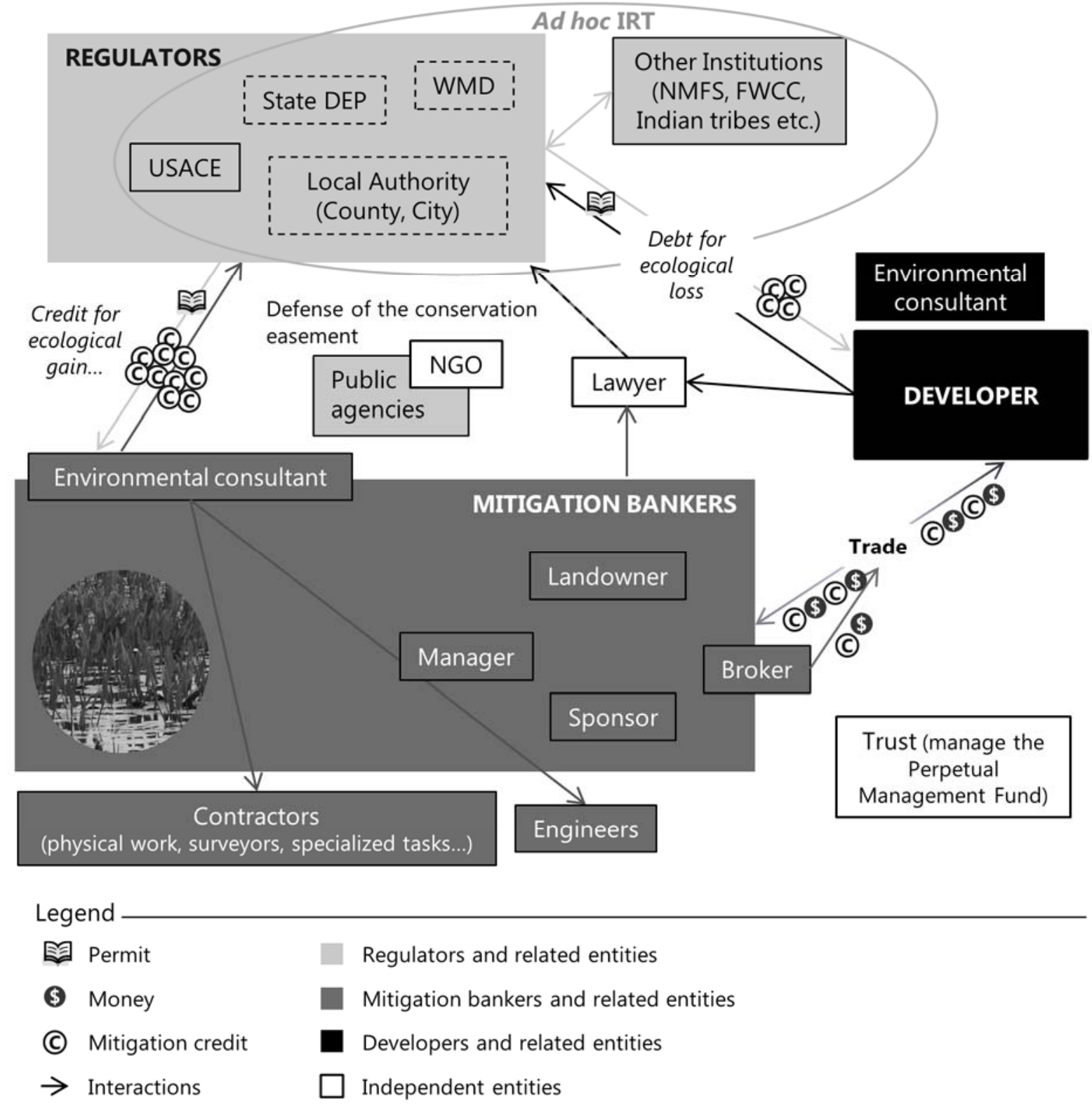


Box 1: Examples of financing arrangements for public/private and public mitigation banks - A public/private bank on publicly owned land: $10 \%$ of the revenue or $50 \%$ of the profit is transferred to the public landowner. This money finances other governmental environment projects.

- A public bank on private land: $20 \%$ of the profit is kept by the public sponsor to pay for the implementation of the management plan and to finance other governmental environment projects. The remaining $80 \%$ of the profit is transferred to the private landowner.

- A bank in which the sponsor is an NGO on private land: the NGO has a special duty to maintain its non-profit status. It repays its actual costs with the revenues and passes the variable extra amount of money to its private partner.

Box 2: Barriers to entry and dumping

This is an example in Florida with the bank $\mathrm{New}^{10}$ that wanted to get established in the same service area as the already established bank Here. The bank Here had already invested USD 10 million in the restoration of a cheap parcel of land. Their permit having been approved in 1999, they were ready to sell their first released credits in 2001 for USD 100,000 per credit. They experienced a prosperous period, during which the demand for compensation was high thanks to a strong economy and during which they had no competitors. They sold a large part of their credits. The bank New planned to invest USD 13 million for a more ambitious restoration on a more expensive parcel of land than that of Here. The restoration project of New was to transform a former arm of river bordered by a forested wetland (converted into a citrus farm) into a wetland delivering a maximum of palustrine emergent credits. This creation project is more ambitious than the restoration project of Here because the original nature of the wetland was forested and not herbaceous. Implementation costs are more significant: the ground has to be excavated in order to enlarge the original size of the arm of river. This is a strategic investment because palustrine emergent credits command a higher price and are more in demand than palustrine forested credits in this area. New was ready to be approved in 2000 but, between 2000 and 2006, surprisingly, Here filed a complaint at the local WMD regarding the negative financial impact of the bank New on the bank Here. Thus between 2000 and 2006, Here sold for USD 18 million worth of credits generating a profit of 8 million while New saw its debt increase because its credits had not been released. In 2009, at the beginning of the global financial crisis, New finally had its first credits released. New

\footnotetext{
${ }^{10}$ The names of the banks have been changed in order to respect the anonymity of the interviews.
} 
was planning on selling their credits at the price of USD 125,000 but decided to sell the first ones at the price of USD 80,000, thus expecting to have a competitive advantage over Here; this was indeed the case for 6 months. Since Here had already recovered its investment, it could afford to lower its credits to the price of USD 50,000. Then the effect of competition kicked in: New lowered its credits to the price of USD 45,000 and Here to the price of USD 30,000, then New to the price of USD 20,000 and finally Here to the price of USD 5,000. New could not go any lower because they would then have never been able to repay their debts. After a discussion with the USACE and the FDEP, New abandoned the project and the bank was suspended. A person closely related to this story's actors says: "They have left New bleeding on the public place." The bank New went bankrupt after having sold 17 credits to developers. To perpetuate the environmental action represented by these 17 credits sold to offset several impacts, the USACE has recovered the long-term fund. The USACE finances the rest of the implementation of the management plan, but only for an estimated surface area equivalent to the 17 sold credits. The rest of the bank area is not considered in good enough shape to warrant investment in restoration. The whole bank has been turned into a Conservation Area. The conservation easement has not changed and is still handled by the State of Florida. 
Table 1: Sample of interviewed actors of the mitigation banking system of Florida

\begin{tabular}{|c|c|c|c|}
\hline \multicolumn{2}{|l|}{ Role } & \multicolumn{2}{|c|}{\begin{tabular}{|l}
$\begin{array}{l}\text { Number of } \\
\text { actors }\end{array}$ \\
\end{tabular}} \\
\hline \multicolumn{2}{|c|}{ Environmental consultant } & \multicolumn{2}{|r|}{20} \\
\hline \multirow{3}{*}{ Mitigation banker } & Landowner & 13 & \multirow{3}{*}{28} \\
\hline & Manager & 17 & \\
\hline & Mix & 12 & \\
\hline \multicolumn{2}{|l|}{ Regulator } & \multicolumn{2}{|r|}{7} \\
\hline \multicolumn{2}{|c|}{$\begin{array}{l}\text { Other professions (broker, lawyer or } \\
\text { academic) }\end{array}$} & \multicolumn{2}{|r|}{10} \\
\hline \multicolumn{2}{|l|}{ TOTAL } & \multicolumn{2}{|r|}{54} \\
\hline
\end{tabular}


Table 2: Three fundamental criteria of hybrid forms (from Ménard 2003 and 2004)

\begin{tabular}{|l|l|}
\hline Regularity & Description \\
resources & $\begin{array}{l}\text { - Coordination and cooperation (common investments), continuity in the } \\
\text { relationship } \\
\text { - Selective rather than open systems (choice of partners, barriers to entry or to } \\
\text { exit from the system) } \\
\text { - Necessary joint planning (may concern inputs, quantity, quality standards, } \\
\text { price, training of personnel, decomposing tasks) } \\
\text { - Adequate information system among partners }\end{array}$ \\
\hline Contracting & $\begin{array}{l}\text { - Well defined contracts among identified partners } \\
\text { - Long-term contracts or frequently renewed short term contracts } \\
\text { - Deliberate incomplete contracts in case of uncertainties linked to specific } \\
\text { assets (possible adjustments and re-negotiations, people usually in charge of } \\
\text { adaptation and solving of conflicts) }\end{array}$ \\
\hline Competing & $\begin{array}{l}\text { - Importance of competitive pressure (internally but also externally with the } \\
\text { other organizational forms) } \\
\text { - risk of individual opportunistic behaviors or migration of partners from one } \\
\text { organizational form to another leads to the implementation of internal mode } \\
\text { of regulation and control }\end{array}$ \\
\hline
\end{tabular}


Table 3: Example of discount or extra-fees for the purchase of ratio credits in 2007 for a public/private bank

\begin{tabular}{|l|l|}
\hline Number of purchased credits & Price/Credit \\
\hline 1 to 4 & USD 49,500 \\
\hline 5 to 9 & USD 47,500 \\
\hline 10 and over & USD 37,500 \\
\hline Fractional (.1 to .8) & USD 5,500 ${ }^{\text {a }}$ \\
\hline
\end{tabular}


Table 4: The characteristics and features of the mitigation banking system halfway between market and hierarchy

\begin{tabular}{|c|c|c|}
\hline Criteria & Approaches the market & Approaches the hierarchy \\
\hline "Voluntarity" a & $\begin{array}{l}\text { Freedom of choice between several } \\
\text { banks in case of an oligopoly or } \\
\text { when negotiating with regulators to } \\
\text { use another compensation tool }\end{array}$ & $\begin{array}{l}\text { Freedom of choice restricted by the } \\
\text { federal preference for mitigation } \\
\text { banking } \\
\text { Trade ordered and approved by the } \\
\text { regulator, who is still responsible for } \\
\text { a large part of the steps in mitigation } \\
\text { banking system implementation } \\
\text { (including supervision of permitting } \\
\text { process, monitoring approval and } \\
\text { control) }\end{array}$ \\
\hline Specificity $^{a}$ & $\begin{array}{l}\text { The mitigation bank sponsor and the } \\
\text { developer precisely know the terms } \\
\text { of the transaction: transfer of } \\
\text { responsibility }\end{array}$ & $\begin{array}{l}\text { Mitigation banking instrument and } \\
\text { permits issued to mitigation bank } \\
\text { sponsors or to developers remain } \\
\text { incomplete so as to be adaptable } \\
\text { over time and to the scale of projects }\end{array}$ \\
\hline $\begin{array}{l}\text { Regularity and } \\
\text { typification }^{\text {a }}\end{array}$ & $\begin{array}{l}\text { Some types of homogeneous credits } \\
\text { easily tradable on a service area }\end{array}$ & $\begin{array}{l}\text { Complexity of credits doubly } \\
\text { negotiated for the same action } \\
\text { (quantity and price) and varying } \\
\text { according to the assessment method } \\
\text { Customers not necessarily regular }\end{array}$ \\
\hline \multirow[t]{3}{*}{ Competition $^{\mathrm{a}}$} & $\begin{array}{l}\text { Terms of the transaction (price) } \\
\text { established between the mitigation } \\
\text { banker and the developer } \\
\text { Interactions and strategies between } \\
\text { the actors of the transaction (buyers } \\
\text { and sellers) }\end{array}$ & $\begin{array}{l}\text { Transaction approved by regulators } \\
\text { More constraints on the } \\
\text { competitiveness of public/private } \\
\text { banks than on private banks }\end{array}$ \\
\hline & Oligopoly in a service area & Monopoly ${ }^{\mathrm{b}}$ in a service area \\
\hline & $\begin{array}{l}\text { Entry of a bank in a market (service } \\
\text { area) may be refused to prevent } \\
\text { excessive competition and thus } \\
\text { maintain the interests of individuals }\end{array}$ & $\begin{array}{l}\text { Entry of a bank in a market (service } \\
\text { area) may be refused to prevent } \\
\text { excessive competition and thus } \\
\text { maintain the interests of the } \\
\text { organization }\end{array}$ \\
\hline
\end{tabular}

\footnotetext{
${ }^{\mathrm{a}}$ Rosenbaum (2000)
}

${ }^{b}$ The commodity is the mitigation credit and not the offset solution. If the offset solution was the commodity, it would not be a monopoly because the buyer can move to another available type of offset (ILF or PRM). However, the preference for mitigation banking hinders this freedom of choice. 


\section{ELECTRONIC SUPPLEMENTARY MATERIAL}

\section{Electronic appendix A: Interview outline of the inquiry on Jacksonville District mitigation banks}

1 Governance

1.1 Governance of the bank

- History of the bank: Original condition, choices/strategies (why mitigation bank vs. permit, ILF?), what difficulties and uncertainties were faced (what adjustments were made during the work)?

- Who is who? Who does what? Map of the actors of the mitigation banking system on the level of the bank/of your company.

- Major links (alliance, liability, conflicts, support). Formal links: contracts, partnership? Informal links: trust, habit, reputation?

- Your role in the bank: your career (education, previous positions).

- Who fill the RIBITS database? Do you consult the website? Do you like it? Do you use the RIBITS or FL-DEP website more often?

- Number of restored acres for each compensated acre

1.2 Mitigation banking system

- Who is the environmental actor in the mitigation banking system?

- Give your opinion on the environmental aim of mitigation banks. Which position: in favor, against, won over, concession, consensus? Give your opinion on compensatory mitigation in general.

- Ecological efficacy? Which criteria? Three levels for determining equivalence: ecological, spatial, temporal efficacy. What are the main criteria to reach these 3 levels of equivalence?

- What should be the balance between avoid, mitigate and offset (mitigation hierarchy)?

- Do you feel that mitigation banks are more effective than PRM/ILF?

- Does your district apply the preference structure of the rule: 1/ Mitigation Banks, 2/ILF and 3/PRM? Another structure? Has the 2008 rule changed anything?

- Influence of the regulators on bank demand: Slow down the bank approval process? Change ecological standards (force mid-way adjustments)? Are you under the impression that the regulators boost or stall mitigation banking in the Jacksonville district? Are regulatory decisions transparent?

- Relations with the regulators: conflicts, trust?

- Obtaining the banking instrument: timeline? Need help to obtain it? 
- Administration (institutional dynamics, legal aspects, rules of the game for mitigation banking etc.). Variability of administrative constraints: rules, procedures, bill of specifications, turnover of the people in charge of the cases, etc.

- Is there a lobby for mitigation banking? How could a lobby influence the mitigation banking system: by making the regulatory framework stronger or the guidelines more precise? What influences the success of mitigation banking?

2 Uncertainties

\section{$2.1 \quad$ Environmental}

- Uncertainty/risk of environmental success. Restoration failure and degradation: risk of statutory non compliance?

- Conservation easement. How does it work? Does the banker have to maintain the bank? Does he have to allow public access to the bank? On what time scale? Durability of mitigation banks.

- Is environmental variability a constraint? If yes, what are the main constraints? How do you handle them?

\subsection{Institutional environment}

- 2008 Rule. How? Do you feel it is better, worse? Does it make mitigation approval easier or more difficult? Why?

- Are you confident about its outcome for mitigation banking (role of the 2008 rule)? Anticipated demand?

- Has the Rule reduced the financial risk of establishing mitigation banks in your district? Why? Influence of the Rule on the availability of compensatory mitigation credit from banks? (Increased/ decreased/ had no effect and why?)

- Do the assessment /control/monitoring/sanction methods play a role in the success of mitigation banking?

\subsection{Behaviors}

- What are your strategies to get around these uncertainties?

- Does increasing the frequency of interactions decrease uncertainties?

- Do you know bankers who have strategic/opportunistic or disloyal competitive behaviors?

- Adaptation to the 2008 rule. What are your main apprehensions/expectations regarding the evolution of the regulatory framework?

- Crisis situation? Adaptation to this crisis?

- Changes during the last years? What were your strategies of adaptation? 


\subsection{Credits}

- How precise are you about what is behind the name of the credits? Use a label or more/less precise description in RIBITS database?

- How do you determine the credits' value? Assessment methods?

- How important is respecting ecological equivalence (no-net-loss principle)?

- What is the role of the ratios: is it a lever for the authorities?

- How do the USACE/FWS exercise control?

- Who approves the credits and corresponding costs for each step?

- Which actors influence the approval of the credits?

- What is the role of the Interagency Review Team?

- What strategy do you use regarding specificity of assets? Do you try to decrease it or do you benefit from market niche situations in service areas.

\subsection{Ecological engineering}

- Restoration, preservation, enhancement, restoration/creation actions. Role of the buffer zones?

- Details about ecological engineering actions (methods, who did it, who decides what actions would be taken).

- Relative scarcity of the ecosystem of the bank. Easier if the ecosystem is less specific?

- Do you feel you are transforming/ changing the environment? Does it depend on where the restoration actions are done: a different natural area (not a wetland) versus a modified natural area (agriculture, urbanization)? Do you try to choose areas where you can reconnect local hydrological systems?

- How do bankers trade off between restoration costs and ecological efficacy of the bank?

$4 \quad$ Credits market and its condition

- Who buys? Why are banks used more than PRM and ILF? How many credits?

- What is the current trend for supply? Is there a risk of flooding the market with credits (too much supply)? Is there regulation of the number of banks based on HUC, district/other factors?

- Condition of the market: oligopolistic, monopolistic or competitive? Is it the same everywhere? What is the current trend?

- Competition regarding the price or the quality: dumping risk with the lowest bidders? Examples? Is mitigation banking competitive? 
- Discuss the risk of not having a return on their investments in the short-term but also in the long term. How many years before you have a return on your investments? Is it slower/quicker since the regulatory framework has been strengthened?

- How does the Rule affect the financial risk experienced by mitigation bankers? (not only supply/demand tension, but also current and future regulator actions)

- Service areas. Very specific market, what is the size of the market? What do you think of this restriction on selling credits? How are these restrictions respected or circumvented? How much leeway is there (for instance, can one pay more to buy more distant credits)? What is the usual scale for the service areas: HUC (8 or 12 digits), geographic regions, hydrologic basin? Is it the same in the different districts? Have the service areas changed in the last few years? How?

- Economic efficacy? How do economic goals affect the ecological management of the site?

- How do you determine your credit price? What are the prices of the credits you sell?

- Is there a risk of financialization of the mitigation banking market: speculation?

Can mitigation bankers sell credits to people who do not necessarily do construction on wetlands? For instance, people who wish to invest in credits or people who wish to compensate for other polluting activities (what kinds of equivalences exist for this purchase?)

$5 \quad$ Study on marine environment

- Difference between terrestrial/estuarine banks, which strategy is preferable?

- What other types of ecological compensatory mitigation do you know? Are you familiar with marine environments?

- Suitability of marine environments to carry out ecological compensatory mitigation? Seabed property, regulatory system, which possible conventions (marine law is still incomplete)?

- Opinion on marine mitigation banking? Is ecological engineering less developed and/or more expensive in marine/coastal areas? Are marine/coastal areas more risky (coastal flooding, oil spill, rising water levels due to climate change)?

- Do you think mitigation banks might be located in the open sea? What are the main barriers (seabed property, other). Do you have any ongoing projects in this area?

6 Conclusion

- Is the Florida/Jacksonville case study representative of what is going on in the other states/regions in the United States?

- What other topics have we not discussed? Do you have additional comments? 


\section{Electronic appendix B: Respondents}

\begin{tabular}{|c|c|c|c|c|c|c|c|c|c|c|c|c|}
\hline \multirow{2}{*}{$\begin{array}{l}\text { Meeting } \\
\text { number }\end{array}$} & \multicolumn{7}{|c|}{ Role } & \multicolumn{5}{|c|}{ Background } \\
\hline & $\begin{array}{l}\text { Environmental } \\
\text { consultant }\end{array}$ & $\begin{array}{l}\text { Banker/ } \\
\text { Landowner }\end{array}$ & $\begin{array}{l}\text { Banker / } \\
\text { Manager }\end{array}$ & $\begin{array}{l}\text { Banker / } \\
\text { Mixed status }\end{array}$ & Broker & Regulator & Other & Scientist & Development & Business & Regulator & Other \\
\hline 1 & & & $\mathrm{x}$ & & & & & & & & & $\mathrm{x}$ \\
\hline 2 & & $\mathrm{x}$ & & & & & & & $\mathrm{x}$ & $\mathrm{X}$ & & \\
\hline 3 & & & & & & & $\mathrm{x}$ & & & & & $\mathrm{X}$ \\
\hline 4 & $\mathrm{x}$ & & & & & & & $\mathrm{x}$ & & & & \\
\hline 5 & $\mathrm{x}$ & $\mathrm{x}$ & $\mathrm{x}$ & & $\mathrm{x}$ & & & $\mathrm{x}$ & & & $\mathrm{x}$ & \\
\hline 6 & & $\mathrm{x}$ & $\mathrm{x}$ & & & & & & $\mathrm{x}$ & & & \\
\hline 7 & & $\mathrm{x}$ & & & & & & $\mathrm{x}$ & & & & \\
\hline 8 & & & & & & $\mathrm{x}$ & & $\mathrm{x}$ & & & $\mathrm{x}$ & \\
\hline 9 & & & $\mathrm{x}$ & & & & & & $\mathrm{x}$ & & & \\
\hline 10 & & & $\mathrm{x}$ & & & $\mathrm{x}$ & & $\mathrm{x}$ & & & $\mathrm{x}$ & \\
\hline 11 & & & & & & $\mathrm{x}$ & & & & & $\mathrm{x}$ & $\mathrm{x}$ \\
\hline 12 & & & & $\mathrm{X}$ & $\mathrm{x}$ & & & & & $\mathrm{x}$ & & \\
\hline 13 & $\mathrm{x}$ & & $\mathrm{x}$ & & & & & $\mathrm{x}$ & & & $\mathrm{x}$ & \\
\hline 14 & $\mathrm{x}$ & & & & & & & $\mathrm{x}$ & & & & \\
\hline 15 & & & $\mathrm{x}$ & & & & & $\mathrm{x}$ & & & & \\
\hline 16 & $\mathrm{x}$ & & & $\mathrm{X}$ & & & & $\mathrm{x}$ & & & & \\
\hline 17 & $\mathrm{x}$ & & $\mathrm{x}$ & & & & & $\mathrm{x}$ & & & $\mathrm{x}$ & \\
\hline 18 & & & & & $\mathrm{x}$ & & & & & & & $\mathrm{x}$ \\
\hline 19 & & & & & & $\mathrm{x}$ & & $\mathrm{x}$ & & & $\mathrm{x}$ & \\
\hline 20 & $\mathrm{x}$ & & & & & & & $\mathrm{x}$ & & & & \\
\hline 21 & $\mathrm{x}$ & & $\mathrm{x}$ & & & & & $\mathrm{x}$ & & & & \\
\hline 22 & & $\mathrm{x}$ & $\mathrm{x}$ & $\mathrm{X}$ & & & & & & $\mathrm{X}$ & & \\
\hline 23 & & & & & & & $\mathrm{x}$ & & & & & $\mathrm{x}$ (law) \\
\hline 24 & & & $\mathrm{x}$ & $\mathrm{x}$ & & & & & $\mathrm{x}$ & $\mathrm{x}$ & & \\
\hline 25 & & $\mathrm{x}$ & $\mathrm{x}$ & $\mathrm{X}$ & & & & & $\mathrm{x}$ & & & \\
\hline 26 & $\mathrm{x}$ & & & & & & & $\mathrm{x}$ & & & & \\
\hline 27 & $\mathrm{X}$ & & & & & & & $\mathrm{x}$ & & & & \\
\hline 28 & & & & & & & $\mathrm{x}$ & $\mathrm{x}$ & & & & \\
\hline 29 & & & $\mathrm{x}$ & & & & & $\mathrm{x}$ & & & & \\
\hline
\end{tabular}




\begin{tabular}{|c|c|c|c|c|c|c|c|c|c|c|c|c|}
\hline 30 & $\mathrm{x}$ & & & $\mathrm{x}$ & & & & $\mathrm{X}$ & & & & \\
\hline 31 & & & & & $\mathrm{x}$ & & & & & & & $\mathrm{X}$ \\
\hline 32 & & $\mathrm{x}$ & $\mathrm{x}$ & & & & & & & & & $\mathrm{X}$ \\
\hline 33 & $\mathrm{X}$ & & & & & & & $\mathrm{X}$ & & & & \\
\hline 34 & & $\mathrm{x}$ & $\mathrm{x}$ & $\mathrm{x}$ & & & & & & & & $\mathrm{X}$ \\
\hline 35 & $\mathrm{X}$ & & & & & & & $\mathrm{X}$ & & & & \\
\hline 36 & $\mathrm{x}$ & & & & & & & & & & $\mathrm{X}$ & \\
\hline 37 & & & & & & & $\mathrm{x}$ & & & & & $\mathrm{x}$ (law) \\
\hline 38 & & $\mathrm{x}$ & $\mathrm{x}$ & $\mathrm{x}$ & & & & & & & & $\mathrm{x}$ \\
\hline 39 & $\mathrm{x}$ & & & & & & & $\mathrm{X}$ & & & & \\
\hline 40 & & & & $\mathrm{x}$ & & & & $\mathrm{X}$ & & & $\mathrm{x}$ & \\
\hline 41 & & & & & & & $\mathrm{X}$ & & & & & $\mathrm{x}$ (law) \\
\hline 42 & $\mathrm{x}$ & & & & & & & $\mathrm{X}$ & & & & \\
\hline 43 & $\mathrm{x}$ & & & $\mathrm{x}$ & & & & $\mathrm{x}$ & & & & \\
\hline 44 & $\mathrm{X}$ & & & & & & & $\mathrm{X}$ & & & $\mathrm{x}$ & \\
\hline 45 & & $\mathrm{x}$ & & & & & & & & $\mathrm{x}$ & & \\
\hline 46 & $\mathrm{x}$ & & & & & & & $\mathrm{X}$ & & & & \\
\hline 47 & & & $\mathrm{x}$ & $\mathrm{x}$ & & & & $\mathrm{x}$ & & & & \\
\hline 48 & & $\mathrm{X}$ & & & & & & & $\mathrm{x}$ & & & \\
\hline 49 & & & & & & $\mathrm{x}$ & & $\mathrm{x}$ & & & $\mathrm{x}$ & \\
\hline 50 & & & & & & $\mathrm{x}$ & & $\mathrm{X}$ & & & $\mathrm{X}$ & \\
\hline 51 & & & & & & & $\mathrm{X}$ & $\mathrm{X}$ & & & & \\
\hline 52 & & $\mathrm{x}$ & & & & & & $\mathrm{X}$ & & & & \\
\hline 53 & $\mathrm{X}$ & $\mathrm{X}$ & & $x$ & & & & $\mathrm{x}$ & & & & \\
\hline 54 & & & & & & $\mathrm{x}$ & & $\mathrm{X}$ & & & $\mathrm{X}$ & \\
\hline \multirow{2}{*}{$\begin{array}{l}\text { Total } \\
\text { (54) }\end{array}$} & \multirow[t]{2}{*}{20} & 13 & 17 & 12 & \multirow[t]{2}{*}{4} & \multirow[t]{2}{*}{7} & \multirow[t]{2}{*}{6} & \multirow[t]{2}{*}{33} & \multirow[t]{2}{*}{6} & \multirow[t]{2}{*}{5} & \multirow[t]{2}{*}{13} & \multirow[t]{2}{*}{11} \\
\hline & & 28 & & & & & & & & & & \\
\hline
\end{tabular}

${ }^{\mathrm{a}}$ Mixed status $=$ other tasks such as operating the bank or selling the credits. 
Electronic appendix C: Mitigation banks of Florida discussed during the interviews

\begin{tabular}{|l|l|}
\hline Approved (54) & Port Orange \\
\hline Barberville & Reedy Creek \\
\hline Bear Point & San Pedro Bay \\
\hline Big Cypress & Sand Hill Lakes \\
\hline Big Cypress, Phase VI & Southport Ranch \\
\hline Blackwater Creek & St. Marks River \\
\hline Bluefield Ranch & Star 4 \\
\hline Boran Ranch Wetlands & Sundew \\
\hline Breakfast Point & Sweetwater \\
\hline Brick Road & Tampa Bay \\
\hline CGW & Three Lakes Wildlife Mgmt. Area \\
\hline Colbert/Cameron & TM Econ \\
\hline Corkscrew Regional & TM Econ Orange County Phase IV \\
\hline Crosby Island Marsh & Tosohatchee State Reserve \\
\hline Devil's Swamp & Tupelo \\
\hline East Central Florida - Eco Bank & Upper Coastal/Citrus Co \\
\hline Farmton & Wekiva River \\
\hline Fish Tail Swamp & Pending (11) \\
\hline Florida & Bear Creek \\
\hline FP\&L Everglades Phase I & Easter \\
\hline FP\&L Everglades Phase II & Hatchineha Ranch \\
\hline Green Swamp & Hillsborough River \\
\hline Hammock Lake & Horse Creek \\
\hline Highlands Ranch & IMG (Cherry Lake) \\
\hline Lake Louisa \& Green Swamp Ecobank & Jack's Branch \\
\hline Lake Monroe & Mill Creek \\
\hline Lake Swamp & Nochaway \\
\hline Little Pine Island & Pine Island Estuarine \\
\hline Loblolly & Withlacoochee Wetland \\
\hline Loxahatchee & Withdrawn (2) \\
\hline Mary A & Corrigan Ranch \\
\hline Myakka & Heather Island \\
\hline Nokuse & Sold out (2) \\
\hline North Florida Saltwater Marsh & Florida Wetlandsbank \\
\hline North Tampa & Panther Island \\
\hline Northeast Florida Wetland & Suspended (2) \\
\hline Peace River/Hardee Co & Greens Creek \\
\hline Pensacola Bay (Westervelt) & Treasure Coast \\
\hline & \\
\hline
\end{tabular}

